\title{
FINITE-ELEMENT MINIMIZATION OF THE WELDING DISTORTION OF DISSIMILAR JOINTS OF CARBON STEEL AND STAINLESS STEEL
}

\author{
UPORABA KONČNIH ELEMENTOV ZA ZMANJŠANJE POPAČENJA \\ OBLIKE PRI VARJENJU OGLJIKOVEGA IN NERJAVNEGA JEKLA
}

\author{
Eslam Ranjbarnodeh' ${ }^{1}$ Majid Pouranvari ${ }^{2}$, Mehdi Farajpour ${ }^{3}$ \\ ${ }^{1}$ Mining and Metallurgical Engineering Department, Amirkabir University of Technology, Tehran, Iran \\ ${ }^{2}$ Young Researchers Club, Dezful Branch, Islamic Azad University, Dezful, Iran \\ ${ }^{3}$ Department of Mechanical Engineering, Islamic Azad University, East Tehran Branch, Tehran, Iran \\ islam_ranjbar@yahoo.com, islam_ranjbar@aut.ac.ir \\ Prejem rokopisa - received: 2012-08-07; sprejem za objavo - accepted for publication: 2014-05-27
}

doi:10.17222/mit.2012.057

\begin{abstract}
In the present study, on the basis of a verified model, the effects of geometrical and operational variables on the welding distortion of dissimilar joints were investigated. Then, considering the welding current, the fixing time and the sequence of the welding operation, the magnitude of the welding deformation was minimized. The results showed that in the studied dissimilar joint between carbon steel and stainless steel, the minimum distortion occurred when the welding current was about 95 A, the fixing time was $120 \mathrm{~s}$ and the symmetric layout was used.

Keywords: minimization, welding distortion, dissimilar joint, welding variables

V tej študiji je bil preiskovan s preizkušenim modelom vpliv geometrijskih in procesnih spremenljivk na popačenje oblike pri varjenju različnih materialov. Obseg deformacije pri varjenju je bil zmanjšan z upoštevanjem varilnega toka, določitvi časa in zaporedja varilskih operacij. Rezultati pri študiju varjenja ogljikovega in nerjavnega jekla so pokazali, da je najmanjše popačenje oblike doseženo pri varilnem toku okrog $95 \mathrm{~A}$, času $120 \mathrm{~s}$ in simetrični izvedbi varjenja.

Ključne besede: zmanjšanje, popačenje oblike pri varjenju, spajanje različnih materialov, spremenljivke pri varjenju
\end{abstract}

\section{INTRODUCTION}

Dissimilar joints are made of two materials that are considerably different in mechanical and/or chemical senses. Alloying between the base metals and filler metals is of great importance when dissimilar joints are made using fusion-welding processes. The resulting weld metal can show completely different mechanical properties as well as the distribution of the residual stress and the distortion within the weldment compared to the applied base metal(s) and filler metal. In this respect, proper designing of the welding procedure for these welds is of importance to engineers and scientists ${ }^{1}$. In welding operations, residual stresses and distortions are formed in the welded structures due to severe temperature gradients, as they can cause brittle fractures reducing the fatigue life as well as stress corrosion cracking. There are many published studies about the effect of welding residual stresses on the performance of welded structures. For example, Francis et al. ${ }^{2}$ studied the influence of the residual stress in the vicinity of a weld on the structural integrity. They found that the martensite start temperature of the weld filler metal can be adjusted to mitigate the residual-stress distributions in ferritic steel welds.

Klobčar et al. $^{3}$ developed a finite-element model to predict the deformation and residual stresses and detect the areas critical to cracking during the repair welding of complex-geometry tooling.

Francis et al. ${ }^{4}$ reviewed the metallurgical issues that arise in ferritic steel welds, relating them to the difficulties of calculating residual stresses and highlighting some stimulating areas for future research. It should be mentioned that welding residual stresses and distortions are affected by many factors: the thermo-physical and mechanical properties of base metal(s), the geometry of the weldment, the heat input, the welding sequence, etc. ${ }^{5}$ So far, a few studies about the residual stresses in similar as well as dissimilar arc-welding operations have been published. For instance, Sahin et al. ${ }^{6}$ used a two-dimensional finite-element model to predict the residual stresses in a brazed joint between 1.0402 and brass (BS CZ107). They found higher residual stresses in the steel part of the joint with the higher yield strength. Katsareas et al. ${ }^{7}$ developed two-dimensional and three-dimensional models to predict the residual-stress distribution in a dissimilar joint between A508 and 1.4301. They used the element-death-and-birth technique to simulate an addition of the filler metal to the weld pool. Ranjbarnodeh et al. ${ }^{8}$ simulated the heat transfer in dissimilar arc welding of stainless steel to carbon steel. They used the finiteelement software ANSYS to investigate the effects of process parameters on the temperature distribution and residual stresses of a dissimilar joint. According to the 
literature, there are several studies on the effects of welding parameters on the magnitude and distribution of welding residual stresses. Teng et al. ${ }^{9}$ developed a model to evaluate the effects of welding speed, specimen size, mechanical constraint and preheating on residual stresses. In another study, Teng et al. ${ }^{10}$ evaluated the residual stresses with various types of welding sequences in the single-pass welding. But, few researches examined the finite-element simulation of the effect of the welding parameters on the residual distortion. Tsirkas et al. ${ }^{11}$ developed a model to study the effect of the welding speed on the residual stresses and distortion in butt welds of similar butt joints, in which the AH36 steel was used as the base metal. Their results showed that increasing the welding speed greatly affected the welding residual distortion.

Considering the published works on dissimilar joints, further studies are necessary to investigate the welding residual distortions of dissimilar welds, particularly under different welding conditions, as well as the welding sequences and the fixing time in a fixture. Moreover, to the best knowledge of the authors, there is no comprehensive research on the minimization of the welding distortion of dissimilar joints. Therefore, in the present study, a thermo-mechanical model was utilized to evaluate the effects of the welding current, the welding sequence, the fixing time, the similarity and the joint geometry on the residual distortions of dissimilar butt joints of carbon and stainless steels made with the TIG welding process. A finite-element software, ANSYS, was used to solve the governing equations of the heat transfer and elastic-plastic distortion. Finally, considering the fixing time, the welding current and the sequence, the magnitude of the welding distortion was minimized.

\section{MATHEMATICAL MODEL AND EXPERIMENTAL PROCEDURES}

In this work, the finite-element method is employed to solve the heat-conduction problem during and after dissimilar welding. Equation (1) can be employed to describe the temperature variations inside the parts being welded:

$$
\frac{\partial}{\partial x}\left(k \frac{\partial T}{\partial x}\right)+\frac{\partial}{\partial y}\left(k \frac{\partial T}{\partial y}\right)+\frac{\partial}{\partial z}\left(k \frac{\partial T}{\partial z}\right)=\rho C \frac{\partial T}{\partial t}
$$

where $T$ denotes the temperature, $k$ is the thermal conductivity, $C$ is the specific heat, $\rho$ is the density, $t$ represents the welding time, $z$ represents the welding direction, $x$ is the transverse direction and $y$ is the thickness direction. In addition, convection-conduction boundary conditions presented in Equation (2) are assumed, except for the region affected by the welding arc where the Gaussian heat source is employed as the boundary condition as illustrated in Equation (3):

$$
\begin{gathered}
-k \frac{\partial T}{\partial n}=h\left(T-T_{\mathrm{a}}\right) \\
k \frac{\partial T}{\partial y}=q(r)=\frac{\eta V I}{2 \pi r^{2}} \exp \left[-\frac{1}{2}\left(\frac{r}{\sigma}\right)^{2}\right]
\end{gathered}
$$

Here, $n$ denotes the normal direction to the surface boundary, $T_{\mathrm{a}}$ is the ambient temperature, $q(r)$ is the welding input energy, $r$ is the distance from the center of the heat source and $\sigma$ is the Gaussian distribution parameter, which is assumed as the radius of the area to which $95 \%$ of the energy is entered ${ }^{8}$, while $r$ is assumed to be $1.5 \mathrm{~mm}$ and $\eta=0.6 .^{8}$

It should be mentioned that the finite-element software, ANYSYS, is employed to solve the above heatconduction problem. Regarding the thermal response of the material being welded, it is expected to produce a severe temperature gradient close to the welding arc and, therefore, very fine elements are required in the region of the weld pool to archive accurate results. Thus, the mesh is generated in such a way that the size of the elements increases exponentially in the transverse direction, i.e., the $x$-axis. The mesh system used in the model is illustrated in Figure 1. At the same time, the mechanical response of the weldment should be determined by solving the equilibrium problems as shown in Equations (4) and (5):

$$
\begin{gathered}
\sigma_{i j, j}+b_{j}=0 \\
\sigma_{i j}=\sigma_{j i}
\end{gathered}
$$

(a)
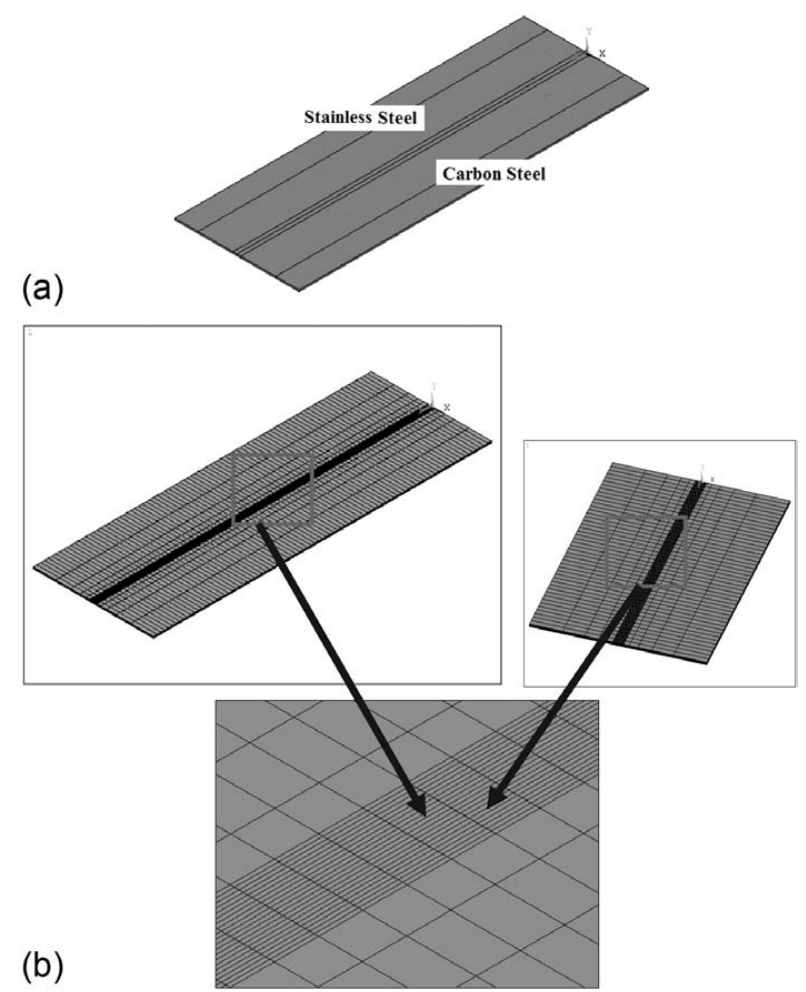

Figure 1: a) Model geometry and b) the used finite-element mesh Slika 1: a) Geometrija modela in b) uporabljena mreža končnih elementov 
where $\sigma_{i j}$ is the Cauchy stress tensor and $b_{i}$ is the body force vector, while the thermo-elastic-plastic behavior, based on the Von Mises yield criterion and the isotropic strain-hardening rule, is considered in the model. Accordingly, the constitutive equations can be written as follows: 6

$$
[\mathrm{d} \sigma]=\left[D^{\mathrm{ep}}\right][\mathrm{d} \varepsilon]-\left[C^{\text {th }}\right] \mathrm{d} T
$$

where $D^{\text {ep }}$ is the elastic-plastic matrix, $C^{\text {th }}$ is the thermal strain matrix, $\mathrm{d} \sigma$ is the stress increment, $\mathrm{d} \varepsilon$ is the strain increment and $\mathrm{d} T$ is the temperature increment. Since the thermal elastic-plastic analysis is a non-linear and path-dependent problem, the incremental calculations, together with the iterative solution techniques, are employed in the model.

It is worth noting that, in the finite-element analysis, for the short samples a total of 5670 elements and 7130 nodes were employed, while for the long samples a total of 11340 elements and 14105 nodes were used in the analysis. The temperature-dependent material properties are assumed for both the stainless-steel and low-carbonsteel parts. The convection heat-transfer coefficient was taken as $25 \mathrm{~W} /\left(\mathrm{m}^{2} \mathrm{~K}\right)$ for the surfaces in contact. The total duration of the joining process consisted of two main parts in the model. The first part was used to complete the welding stage and the remaining time was used to perform the cooling in and out of the fixture. During and after the welding stage the model was constrained in order to prevent a rigid body motion. It should be noted that for the mechanical part of the simulation the results of the thermal part were applied as the body force and thermal stresses were calculated at each step, in other words, the thermo-mechanical problem was handled as a sequentially coupled one. ${ }^{8}$ Using the validated model $^{8}$, the simulations were repeated for different lengths, thicknesses, welding currents, welding sequences and holding times of the fixture and similar joint. Table 1 shows the chemical compositions of the steels used in the welding experiments. The dimensions of the samples were $L \times 80 \times t\left(\mathrm{~mm}^{3}\right)$ where $L$ is the sample length and $t$ is the sample thickness, but the filler was not used. The welding parameters used for preparing

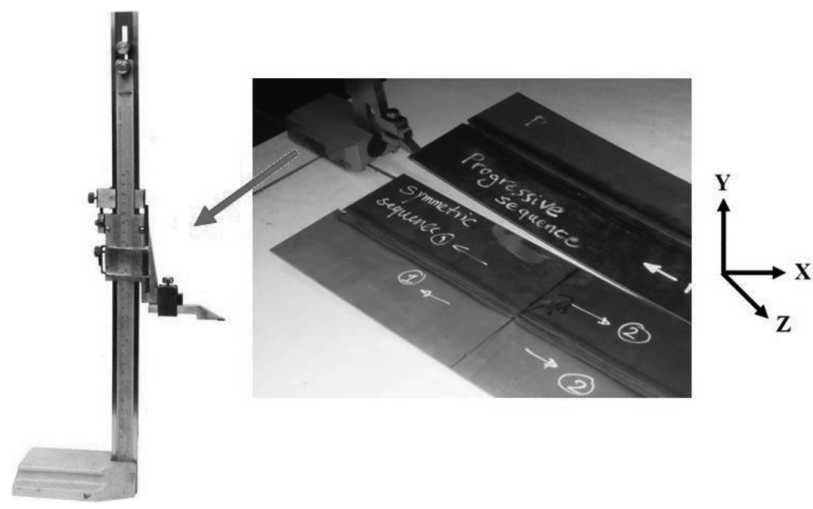

Figure 2: Measurement setup for the welding-induced distortion Slika 2: Merjenje popačenja oblike zaradi varjenja the experimental samples are shown in Table 2. The welding speed was $3.56 \mathrm{~mm} / \mathrm{s}$ for all the samples. After the completion of the joints, the maximum magnitude of the welding distortion of all the samples was measured using a height gauge in the $Y$-direction as shown in Figure 2 and the resulting distortions were compared with the computed results.

Table 1: Chemical compositions of the applied base metals in mass fractions, $w / \%$

Tabela 1: Kemijska sestava uporabljenih jekel v masnih deležih, w/\%

\begin{tabular}{|c|c|c|c|c|c|c|}
\hline Material & $\mathrm{C}$ & $\mathrm{Si}$ & $\mathrm{Mn}$ & $\mathrm{Ni}$ & $\mathrm{Cr}$ & $\mathrm{Ti}$ \\
\hline $\begin{array}{c}\text { Stainless steel } \\
\text { (AISI409) }\end{array}$ & 0.015 & 0.59 & 0.27 & 0.13 & 11.28 & 0.17 \\
\hline $\begin{array}{c}\text { Carbon steel } \\
\text { (CK4) }\end{array}$ & 0.025 & 0.013 & 0.19 & 0.04 & 0.01 & - \\
\hline
\end{tabular}

Table 2: Applied welding parameters

Tabela 2: Uporabljeni parametri varjenja

\begin{tabular}{|l|c|c|c|c|c|}
\hline Joint type & $\begin{array}{c}\text { Welding } \\
\text { sequence }\end{array}$ & $\begin{array}{c}\text { Welding } \\
\text { current } \\
(\mathrm{A})\end{array}$ & $\begin{array}{c}\text { Thick- } \\
\text { ness } \\
(\mathrm{mm})\end{array}$ & $\begin{array}{c}\text { Length } \\
(\mathrm{mm})\end{array}$ & Sample \\
\hline dissimilar & progressive & 120 & 2 & 450 & 120LPD \\
\hline dissimilar & progressive & 120 & 2 & 225 & 120 SPD \\
\hline dissimilar & progressive & 150 & 3 & 225 & 150Thick \\
\hline dissimilar & progressive & 150 & 2 & 225 & 150Thin \\
\hline dissimilar & progressive & 105 & 2 & 450 & 105LPD \\
\hline dissimilar & progressive & 135 & 2 & 450 & 135LPD \\
\hline dissimilar & progressive & 95 & 2 & 450 & 95LPD \\
\hline dissimilar & symmetric & 95 & 2 & 450 & 95LSD \\
\hline similar & progressive & 120 & 2 & 225 & 120SS-SS \\
\hline similar & progressive & 120 & 2 & 225 & 120CS-CS \\
\hline dissimilar & back step & 120 & 2 & 225 & 120SBD \\
\hline dissimilar & symmetric & 120 & 2 & 225 & 120SSD \\
\hline
\end{tabular}

\section{RESULTS AND DISCUSSION}

The comparison of the experimental and simulation results of the distortion measurements are presented in Table 3. As can be seen, there is a logical consistency between the experimental and simulated data. The effect of the sample length on the welding residual distortion was investigated using the samples with two different

Table 3: Comparison between experimental and simulated distortion data

Tabela 3: Primerjava med eksperimentalnimi in simuliranimi podatki o popačenju oblike

\begin{tabular}{|c|c|c|}
\hline $\begin{array}{c}\text { Simulated distortion } \\
(\mathrm{mm})\end{array}$ & $\begin{array}{c}\text { Experimental } \\
\text { distortion }(\mathrm{mm})\end{array}$ & Sample \\
\hline 5.47 & 8.1 & 70 SPD \\
\hline 16.4 & 22.1 & 70LPD \\
\hline 17.6 & 18.5 & 105LPD \\
\hline 4.43 & 6.1 & 120SPD \\
\hline 21.9 & 24.3 & 120LPD \\
\hline 18.2 & 23.1 & 105LPS \\
\hline 19.4 & 24.2 & 120LPS \\
\hline 19.7 & 25.5 & 135LPS \\
\hline 10.2 & 9.8 & 120LPDS \\
\hline
\end{tabular}


(a)

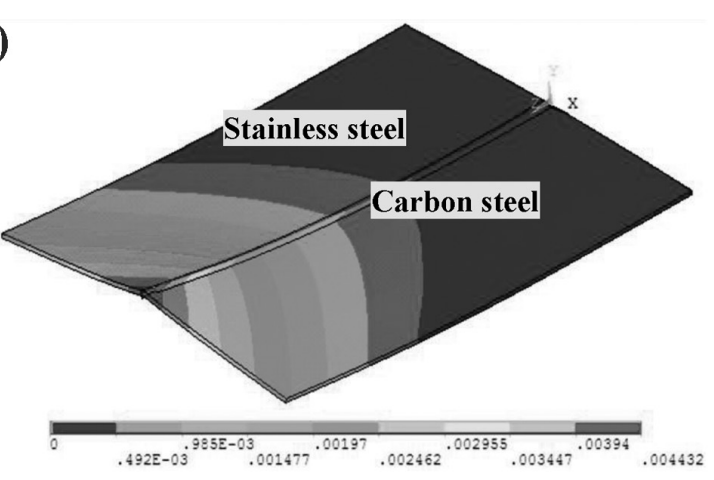

(b)
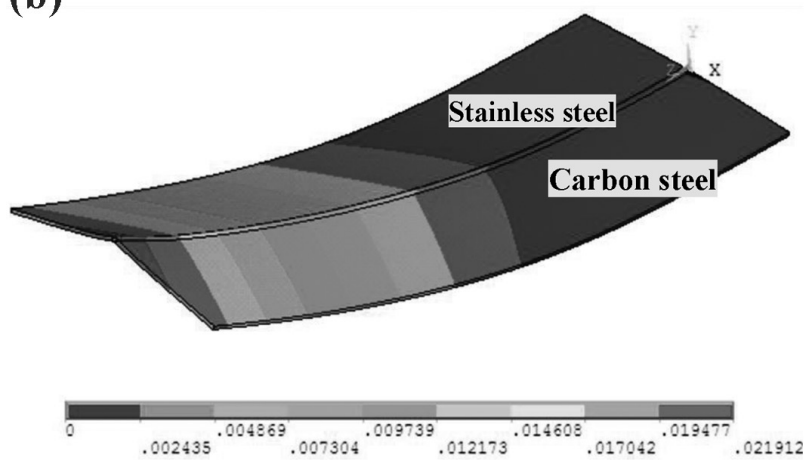

Figure 3: Effect of the length on the welding distortion: a) longer sample, b) shorter sample

Slika 3: Vpliv dolžine na popačenje oblike pri varjenju: a) daljši vzorec, b) krajši vzorec

lengths, 120SPD and 120LPD. The distortion of the longer sample, with twice the length, is over five times larger than that of the shorter sample as shown in Figure 3 . This can be related to the lower stiffness of the longer sample (120LPD). Stiffness is the resistance of a body to distortion due to an applied force. Contrary to elastic modulus, stiffness is not an intrinsic material property. In other words, it depends on the geometry and material property (elastic modulus). For an element in tension or compression, the axial stiffness is defined with Equation (7):

$$
K=\frac{A \times E}{L}=\frac{W \times t \times E}{L}
$$

where $L$ denotes the sample length, $A$ is the cross-sectional area, $E$ is the Young's modulus, $W$ is the width of the specimen and $t$ shows the thickness. The double length of the longer sample causes the half stiffness, i.e., a lower resistance to distortion and, accordingly, a higher welding distortion. The next point is the effect of the thickness on the welding distortion. Figure 4 compares the distortions for two different thicknesses. Again, according to Equation (7), a higher thickness means a higher stiffness. Therefore, the thicker structure is more resistant to distortion. Increasing the thickness

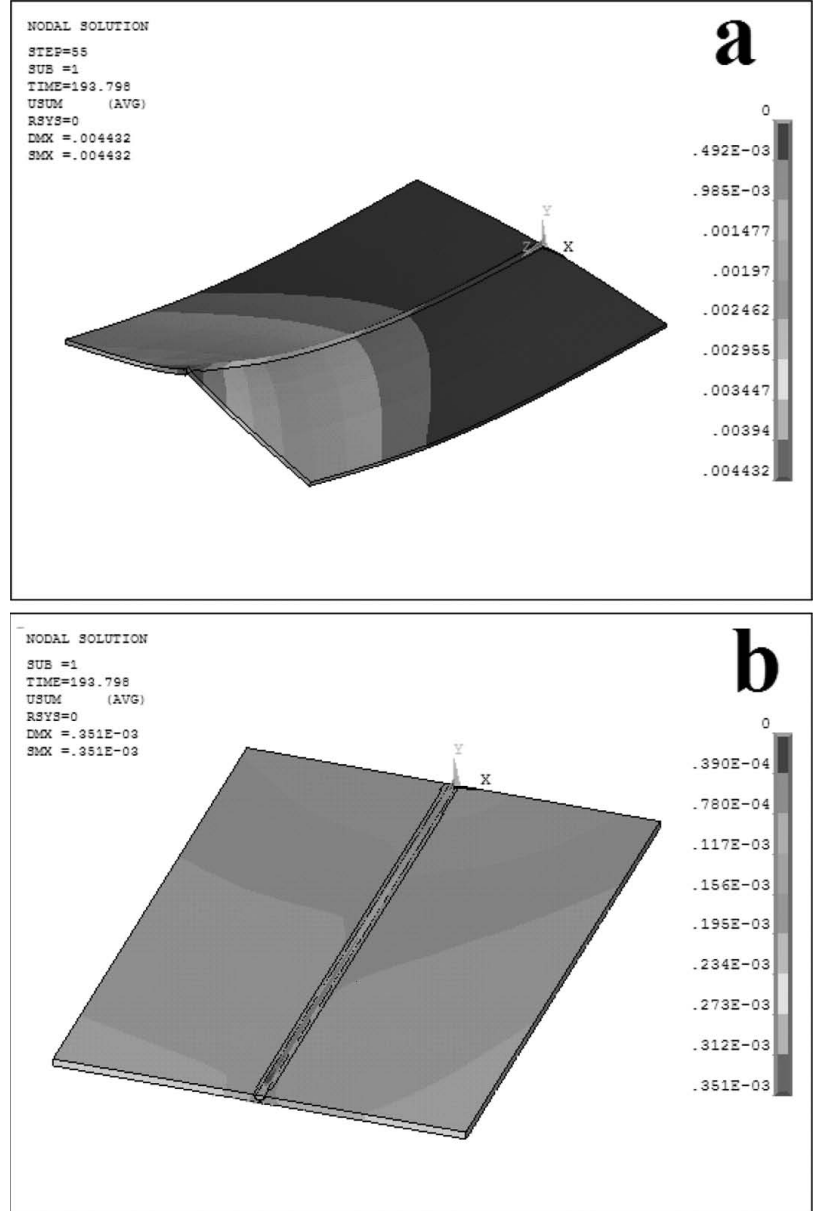

Figure 4: Effect of the thickness on the welding distortion: a) thicker sample $(3 \mathrm{~mm}), \mathrm{b})$ thinner sample $(2 \mathrm{~mm})$

Slika 4: Vpliv debeline na popačenje oblike pri varjenju: a) debelejši vzorec $(3 \mathrm{~mm})$, b) tanjši vzorec $(2 \mathrm{~mm})$

from $2 \mathrm{~mm}$ to $3 \mathrm{~mm}$ decreased the maximum magnitude of distortion from $6.7 \mathrm{~mm}$ to $0.3 \mathrm{~mm}$.

The maximum distortions for different welding currents are compared in Table 4. As expected, a higher welding current induced a higher welding distortion due

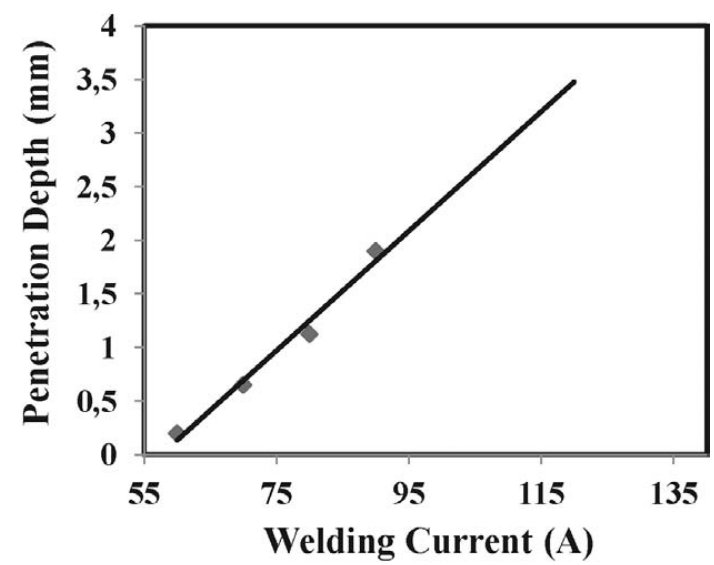

Figure 5: Effect of the welding current on the joint penetration Slika 5: Vpliv varilnega toka na penetracijo v spoju 


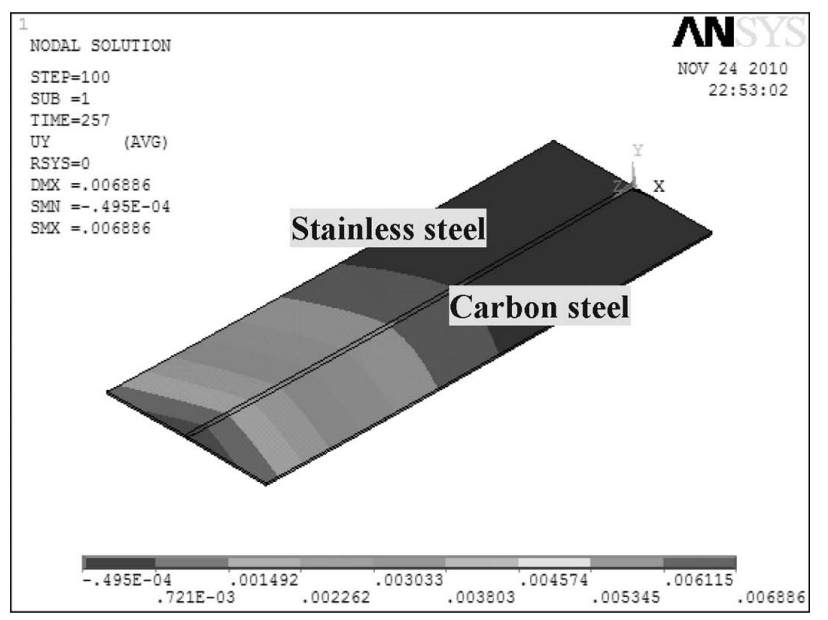

Figure 6: Distortion of sample 95LPD

Slika 6: Popačenje oblike pri vzorcu 95LPD

to a higher welding-heat input. Therefore, it can be concluded that the minimum distortion would be attained for the minimum applicable welding heat input keeping a full penetration. Using the simulation results, the minimum welding current to reach a full penetration was found to be about $95 \mathrm{~A}$, as illustrated in Figure 5. Using this welding current, the simulation was repeated and the result showed that the minimum possible distortion for a progressive layout was about $6.8 \mathrm{~mm}$ (Figure 6).

Table 4: Maximum distortions for different welding currents Tabela 4: Maksimalna popačenja pri različnih tokovih varjenja

\begin{tabular}{|c|c|c|c|}
\hline 135LPD & 120LPD & 105LPD & Sample \\
\hline 135 & 120 & 105 & Welding current (A) \\
\hline 23.7 & 21.9 & 17.6 & Distortion $(\mathrm{mm})$ \\
\hline
\end{tabular}

The effect of the welding sequence on the welding distortion was investigated for three different sequences. Figure 7 shows a schematic illustration of the used welding sequences and Figure 8 indicates the effects of the used welding sequences on distortion. As it is demonstrated, the symmetric layout causes the minimum
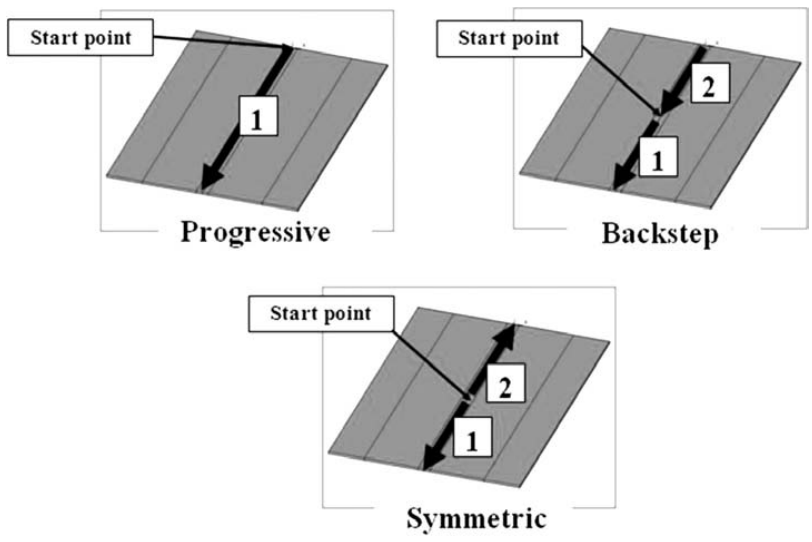

Figure 7: Schematic illustration of the used welding sequences Slika 7: Shematski prikaz uporabljenih sekvenc varjenja residual distortion. This can be due to the movement of the welding heat source from the middle of the plate with the minimum degree of freedom to the endpoint with the highest degree of freedom. It should be noted that this result is in agreement with the other researchers. ${ }^{9,12}$ According to the authors' knowledge there is no detailed numerical study on the effect of the holding time in a

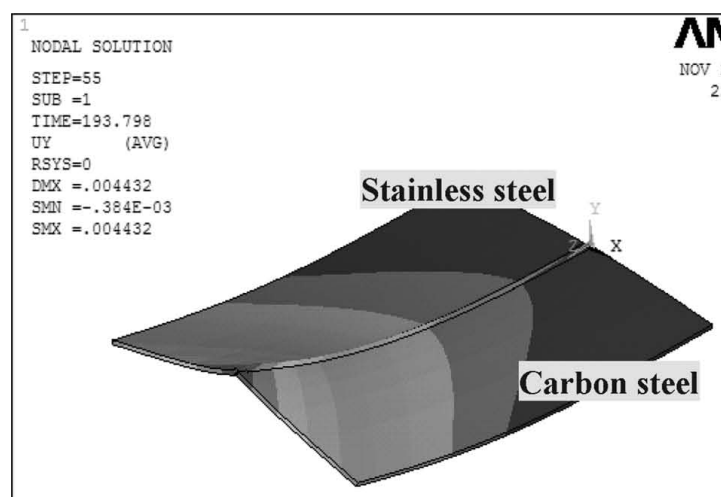

(a) $\frac{-.384 \mathrm{E}-03}{.151 \mathrm{E}-03^{.686 \mathrm{E}-03} .001221^{.001756} .002292^{.002827} .003362^{.003897} .004432}$
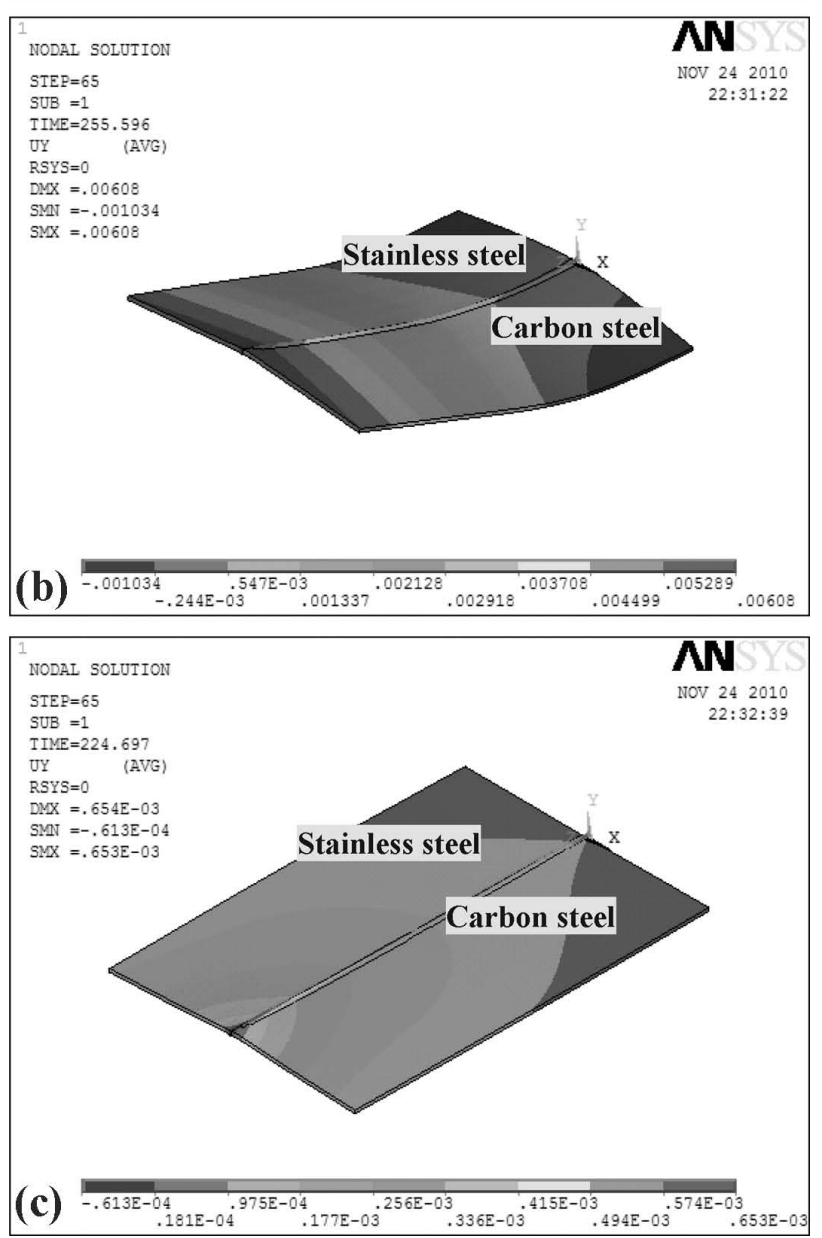

Figure 8: Effect of the welding layout on distortion: a) progressive, b) back-step and c) symmetric welding layout

Slika 8: Vpliv postavitve varjenja na popačenje oblike pri varjenju: a) progresivno, b) s koraki nazaj in c) simetrična postavitev varjenja 


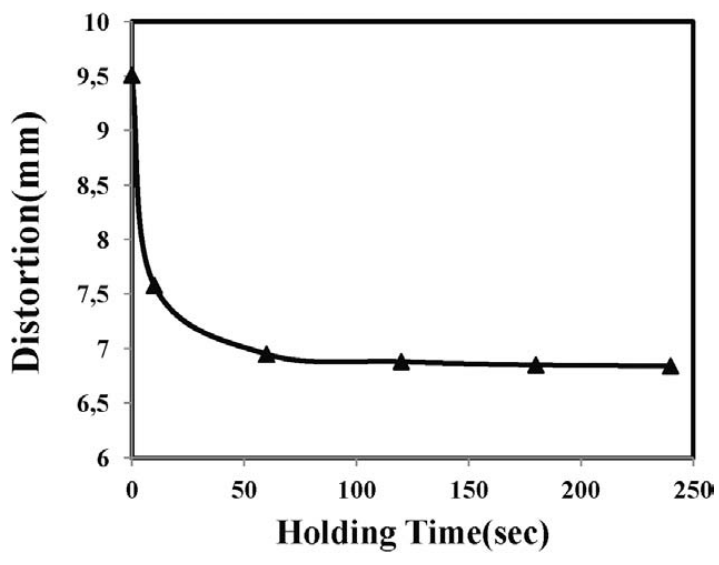

Figure 9: Effect of the holding time in the fixture on distortion Slika 9: Vpliv časa zadržanja v držalu na popačenje oblike

fixture on the welding distortion. The question is what the effect of the holding time in a fixture on the magnitude of distortion is when a structure is welded under mechanical restraint. In order to answer this question the final distortion of sample 95LPD was determined for
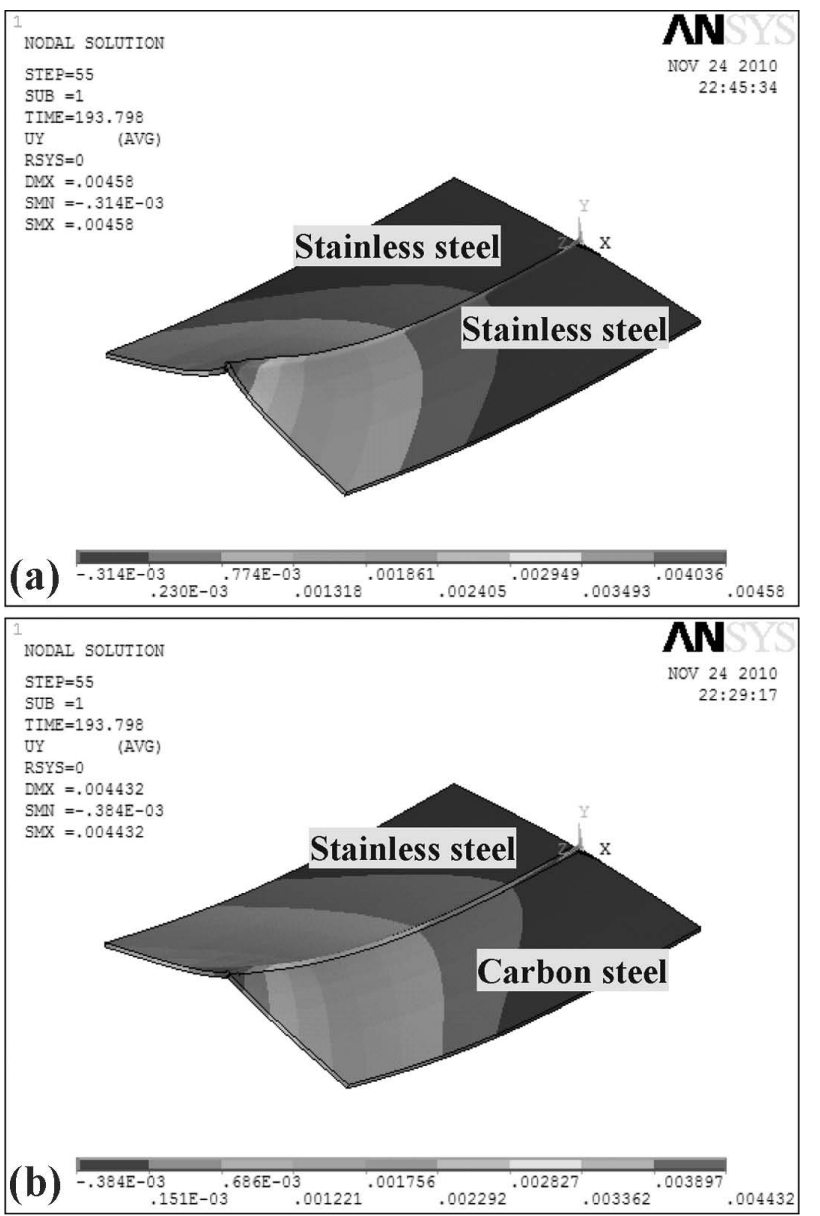

Figure 10: Comparison of the distortions of: a) similar and b) dissimilar joints

Slika 10: Primerjava popačenja oblike pri spajanju: a) enakih in b) različnih materialov

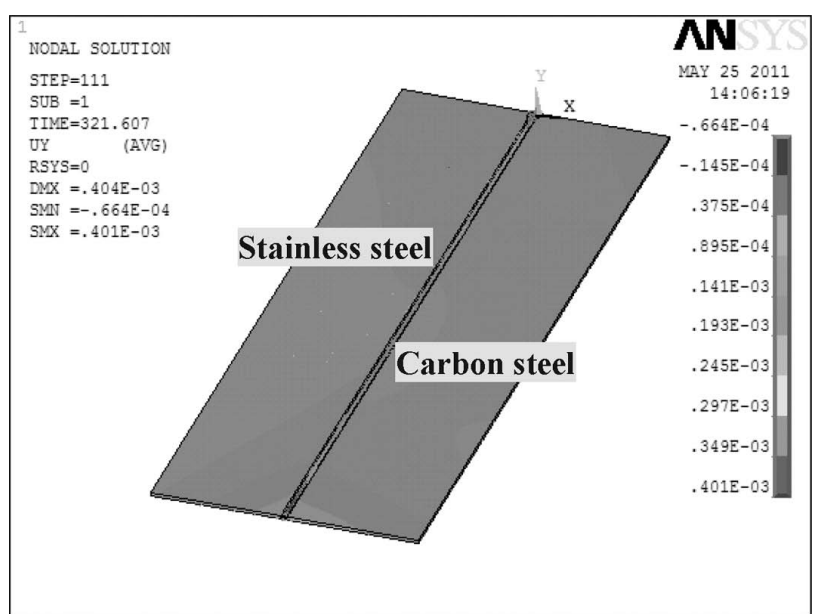

Figure 11: Distortion of sample 95LSD

Slika 11: Sprememba oblike vzorca 95LSD

different holding times in the fixture and afterwards the structure was relaxed due to the removal of the applied mechanical constrains. As depicted in Figure 9, increasing the holding time decreases the residual welding distortion. After $120 \mathrm{~s}$, the distortion-holding time curve enters a plateau region. This means that the joint in the fixture was cooled down and that, after this time, the holding time did not have a significant effect on the final magnitude of distortion. This can be due to the high yield strength of the base metal at room temperature, preventing additional distortion. Figure $\mathbf{1 0}$ compares the distortions of similar and dissimilar joints. It is seen that a similar joint of stainless steel will cause a higher magnitude of distortion in comparison with a dissimilar joint. This may be attributed to the low thermal conductivity, low yield strength and the high thermal-expansion coefficient of stainless steel. Using the previous findings of this study, a simulation was done for different welding currents to reach the minimum welding distortion. The result is depicted in Figure 11. As can be seen, using the minimum welding current (95 A), the symmetric sequence and the 120-second holding time, the final magnitude of the welding distortion can be reduced by only about $0.4 \mathrm{~mm}$ which is very small in comparison with $23.7 \mathrm{~mm}$ for sample 135LPD.

\section{CONCLUSIONS}

In this work, a verified 3D finite-element model $^{8}$ was utilized to evaluate the effects of the geometry, the welding current, the welding sequence, the holding time in the fixture and the similarity of the joint on the welding distortion of a dissimilar joint between carbon steel and stainless steel. Also, considering the welding current, the sequence and the fixing time, the magnitude of the welding distortion was minimized. The results showed that: 
- A higher welding current, i.e., a higher heat input produces a larger distortion.

- Increasing the length and decreasing the thickness of the welded plates reduce the stiffness of the structure and, consequently, increase the welding distortion.

- Due to the low thermal conductivity and yield strength and the high thermal-expansion coefficient, the welding distortion of a similar joint of stainless steel is larger than in the case of a dissimilar joint of carbon steel and stainless steel.

- Increasing the holding time in the fixture first reduces the distortion but after 120 seconds, it no longer has a significant effect.

- The symmetric welding sequence was found to be an effective way to reduce the welding distortion of a joint compared to the other welding layouts applied in the current study.

- The minimum welding distortion in the studied joint can be obtained using the symmetric sequence, the welding current of $95 \mathrm{~A}$ and the holding time of 120 S.

\section{REFERENCES}

${ }^{1}$ Welding handbook, vol. 4, AWS, Miami 1997, 514-515

${ }^{2}$ J. A. Francis, H. J. Stone, S. Kundu, R. B. Rogge, H. K. D. H. Bhadeshia, P. J. Withers, L. Karlsson, Transformation Temperatures and Welding Residual Stresses in Ferritic Steels, Proc. of ASME Pressure Vessels and Piping Conference, San Antonio, 2007, 949-956, doi: 10.1115/PVP2007-26544

${ }^{3}$ D. Klobčar, J. Tušek, B. Taljat, Finite element modeling of GTA weld surfacing applied to hot-work tooling, Comput. Mater. Sci., 31 (2004), 368-378, doi:10.1016/j.commatsci.2004.03.022

${ }^{4}$ J. A. Francis, H. K. D. H. Bhadeshia, P. J. Withers, Mater. Sci. Technol., 23 (2007), 1009-1020, doi:10.1179/174328407X213116

${ }^{5}$ S. Kou, Welding Metallurgy, John Wiley \& Sons, New Jersey 2003, 122

${ }^{6}$ S. Sahin, M. Toparli, I. Ozdemir, S. Sasaki, J. Mater. Process. Technol., 132 (2003), 235-241, doi:10.1016/S0924-0136(02) 00932-9

${ }^{7}$ D. E. Katsareas, A. G. Yostous, Mater. Sci. Forum, 490-491 (2005), 53-61, doi:10.4028/www.scientific.net/MSF.490-491.53

${ }^{8}$ E. Ranjbarnodeh, S. Serajzadeh, A. H. Kokabi, A. Fisher, J. Mater. Sci., 146 (2010), 3225-3232, doi:10.1007/s10853-010-5207-8

${ }^{9}$ T. Teng, C. Lin, Int. J. Press. Vessels Pip., 75 (1998), 857-864, doi: 10.1016/S0308-0161(98)00084-2

${ }^{10}$ T. Teng, T. Chang, W. Tseng, Comput. Struct., 181 (2003), 273-286, doi:10.1016/S0045-7949(02)00447-9

${ }^{11}$ S. A. Tsirkas, P. Papanikos, T. Kermanidis, J. Mater. Process. Technol., 134 (2003), 59-69, doi:10.1016/S0924-0136(02)00921-4

${ }^{12}$ L. Gannon, Y. Liu, N. Pegg, M. Smith, Mar. Struct., 23 (2010), 385-404, doi:10.1016/j.marstruc.2010.05.002 